\title{
Ankylosing spondylitis: introductory comments on its diagnosis and treatment
}

\section{A Khan}

A nkylosing spondylitis (AS) is a chronic systemic inflammatory rheumatic disorder of uncertain aetiology that primarily affects the axial skeleton (sacroiliac joints and spine). Sacroiliac joint involvement (sacroiliitis) is its hallmark. ${ }^{1}$ The course of AS is highly variable and can be characterised by spontaneous remissions and exacerbation, particularly in early disease. The disease activity, however, generally persists for many decades, rarely entering a long term remission. The disease in some patients may be relatively mild or stay limited to the sacroiliac joints and the lumbar spine. Many patients may not seek medical help, which combined with the insidious nature of AS, may preclude an early diagnosis. There is currently no cure for AS, nor is there any medical intervention which can prevent or retard its progression.

\section{DISEASE ONSET TO DIAGNOSIS: A BRIDGE TOO FAR}

Only a doctor who is fully cognisant of the clinical nature of AS might consider the possibility of a spondyloarthropathy (SpA), much less AS, when presented with a young individual in their teens or early to mid-20s with chronic back pain. ${ }^{12}$ Yet, this is a typical initial presentation of AS. Unfortunately, the presence of inflammatory back pain during the clinically unrecognised "pre-spondylitic" phase, which on average might last 5-10 years or longer, is accompanied by progressive structural damage that may take place inconspicuously. ${ }^{1-8}$ Diagnosis is often established when AS reaches the stage where structural damage has led to easily recognisable abnormal physical findings or readily apparent radiographic abnormalities of the sacroiliac joints and spine, or both..$^{1-4}$

Figure 1, which represents data collected by a 78 item professional survey of patients with AS conducted by the German AS society in 1996, illustrates well the protracted time delay between onset of AS and its diagnosis. ${ }^{5}$ A total of 1614 patients with AS responded to the questionnaire. The average age at onset of the disease was 25.7 years, and the average delay in diagnosis was 8.9 years. A significantly greater delay in diagnosis was seen among women than among men (9.8 years $v 8.4$ years; $\mathrm{p}<0.01)$. This discrepancy in disease detection between the sexes reflects the common problem of underdiagnosis of AS among women, probably owing to the misconception that women rarely have AS.

This misconception may also result from slower progression of the typical spinal radiographic manifestations in women with AS. A longitudinal study found that the vast majority $(81 \%)$ of patients with AS had lost most of their spinal mobility within the first 10 years of onset of AS, and that the disease progresses enough to cause severe restriction of spinal mobility in about $40 \%$ of the patients. ${ }^{6}$ Loss of function correlated significantly with radiographic changes of AS in the spine, the development of "bamboo spine," and the occurrence of appendicular (hip and shoulder) and peripheral arthritis. Thus, patients with a definite diagnosis of AS face a lifetime of progressive structural deterioration and associated pain and

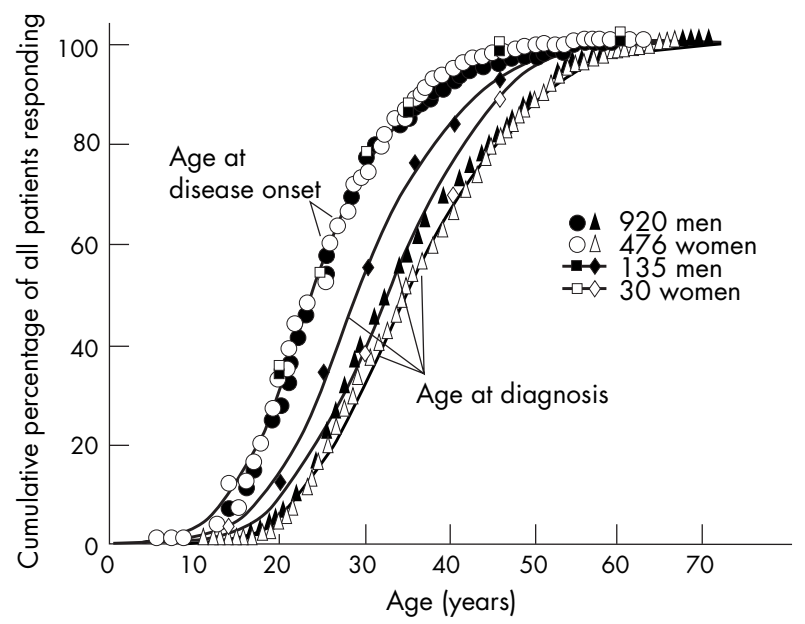

Figure 1 Cumulative distribution of the age at disease onset (occurrence of the first spondylitic symptoms) and of the age at diagnosis for 920 male and $\mathbf{4 7 6}$ female patients with ankylosing spondylitis. Reproduced with permission from the authors and Current Opinion in Rheumatology from reference 5. Copyright (C) 2000 by Lippincott Williams \& Wilkins.

functional disability, which contribute to substantial socioeconomic loss and reduced quality of life. ${ }^{910}$

Many investigators have tried to set and refine guidelines for the diagnosis of AS. The modified New York diagnostic criteria commonly used today are readily applicable to patients showing clear radiological evidence of AS, but they are of limited use in the absence of defined radiological signs. ${ }^{11}$ For example, the definite diagnosis of AS cannot be made unless the patient shows unequivocal radiological evidence of grade II sacroiliitis bilaterally, or grade III sacroiliitis unilaterally. This criterion does not acknowledge juvenile patients or those in their late teens or early twenties with disease activity that has not yet progressed to the point where their sacroiliitis is unequivocally detectable by $x$ ray examination. ${ }^{78}{ }^{12}$ This is also true for those patients who may have an undifferentiated form of SpA that may progress over some years to meet eventually the modified New York criteria established for AS..$^{1-4} 8_{12}^{12}$ Thus, the diagnosis and treatment of AS and related SpA in the early stages may often be related more to patients' clinical presentation and to clinicians' personal experience and intuition than precise diagnostic criteria. This clinical dilemma represents the wide chasm that exists between the onset of AS and its definite diagnosis and, subsequently, its appropriate treatment. Many researchers have attempted to bridge this

Abbreviations: AS, ankylosing spondylitis; DMARDs, disease modifying antirheumatic drugs; NSAIDs, non-steroidal anti-inflammatory drugs; RA, rheumatoid arthritis; TNF $\alpha$, tumour necrosis factor $\alpha$ 
chasm by establishing criteria for the early diagnosis of $\mathrm{AS}^{4}{ }^{13}{ }^{14}$; however, none of these criteria have been universally accepted. Thus, at present, doctors cannot look to established criteria for assistance in detecting early or atypical AS.

Early diagnosis of AS is highly desirable $e^{15}$ because $(a)$ it enables the institution of treatment before permanent limitation of spinal mobility and spinal deformity have set in, and (b) it provides the clinician with the opportunity to monitor trends in spinal pathology that might result in abnormal posture. However, considerable progress is needed to improve the chances of a very early diagnosis of AS. Firstly, a global consensus needs to be reached on criteria for diagnosis and staging of AS - the aspects of clinical management that are fundamental to designing effective treatment strategies. Also, current diagnostic and classification systems for AS do not reflect the broad range of clinical and radiological presentations of the disease. ${ }^{12-14}$ This limits the ability of clinicians to diagnose patients with AS at an early stage and provide proper management.

These needs were recently acknowledged in a questionnaire based survey conducted by the experts participating in the Ankylosing Spondylitis Workshop held in Berlin, Germany, in January 2002, and resulted in a proposal for staging of patients with AS that is presented in this supplement. (see p iiil9) These offerings are an excellent starting point for establishing basic understandings among investigators and clinicians for the evaluation of treatment outcomes.

At present, a wide assortment of methods for assessment of AS has been suggested, ${ }^{16}$ but no particular method has been accepted universally, and no guidelines for the use of assessment measures have been established. Disease outcome depends on the speed of spinal ankylosis. ${ }^{3}$ There are many indicators for a severe disease outcome in patients with AS, such as onset at 16 years of age or younger, severe pain, grade IV radiographic spinal structural damage, limited spinal mobility, significant functional impairment, a need for regular pharmacological intervention, the lack of efficacy of nonsteroidal anti-inflammatory drugs (NSAIDs), a requirement for corticosteroid or sulfasalazine treatment, ocular involvement, hip or knee involvement, and a requirement for surgery. ${ }^{17}$ Recently, the Assessments in Ankylosing Spondylitis Working Group defined a core set of domains for the evaluation of AS in the setting of disease controlling antirheumatic treatment and symptom modifying antirheumatic drug treatment in conjunction with physical therapy, and also for clinical record keeping. ${ }^{18}{ }^{19}$ Which instruments most appropriately assess these domains-for example, the Bath Ankylosing Spondylitis Functional Index (BASFI) or the Dougados Functional Index (DFI) for function, and the visual analogue scale or the Bath AS Disease Activity Index (BASDAI) for pain, have yet to be determined. Moreover, application of the selected instrument in the assessment of treatment outcome, and the definition of treatment efficacy, are other unresolved issues.

\section{TREATMENT: IS IT TIME FOR A CHANGE IN PARADIGMS?}

Perhaps the most disheartening inadequacy in the care of patients with AS is the lack of therapeutic options which significantly impact and slow or halt disease progression. Unarguably, the use of NSAIDs rapidly relieves inflammatory back pain in patients with $\mathrm{AS}^{20-23}$ earning these agents the status as the "gold standard" for drug treatment in AS. ${ }^{20}$ In fact, a dramatic response to NSAID treatment generally confirms the diagnosis of AS in a patient with a high index of clinical suspicion of the disease. ${ }^{24}$ However, patients experience clinical benefit only when they are regularly taking NSAIDs, preferably in full anti-inflammatory dose.

The clinical benefit of these agents does not continue once these drugs are stopped. Furthermore, in many cases, NSAID use is limited by gastrointestinal side effects, with minimal clinical benefit from NSAIDs as the disease progresses. Gastropathy results from the cytotoxic effects of NSAIDs on the gastrointestinal mucosa and occurs in most patients treated with NSAIDs. ${ }^{25}$ Most gastrointestinal symptoms are mild, but serious symptoms can sometimes occur, such as gastrointestinal bleeding and perforation. ${ }^{26}$ The risk of such serious gastrointestinal side effects is reduced by the use of newer but more expensive NSAIDs that selectively inhibit cyclo-oxygenase-2 (COX-2). ${ }^{27-29}$ However, COX-2 inhibitors (the so-called "coxibs") are not more efficacious than conventional NSAIDs, and are not associated with a significantly lower incidence of the more common, less serious gastrointestinal side effects, such as nausea, and dyspepsia that bother most patients..$^{27-30}$ Thus, as effective as NSAIDs may be, their overall clinical benefits are relatively limited.

For patients with AS refractory to NSAID treatment, the employment of disease modifying antirheumatic drugs (DMARDs) has been the second line approach, despite the lack of solid evidence of their efficacy. For example, sulfasalazine treatment is often used, but it is only effective in reducing synovitis in patients with peripheral joint involvement and has no beneficial effect on axial disease. ${ }^{31}{ }^{32}$ Methotrexate is not effective in patients with AS who are unresponsive to NSAIDs and sulfasalazine. ${ }^{33-36}$ The use of some of the other DMARDs has also not been proved to be effective in placebo controlled trials, ${ }^{20}{ }^{37}$ and their use is based primarily on anecdotal reports of efficacy or uncontrolled data. ${ }^{29}{ }^{30}$ Intraarticular injection of corticosteroids into the sacroiliac joint under image enhancement (for example, with computed tomography and magnetic resonance imaging) often provides symptomatic relief for a variable duration, sometimes up to 10 months. ${ }^{38}{ }^{39}$

There is a clear need for effective new drug treatments for AS because no currently available drug can retard the process of fibrous and bony ankylosis and alter the natural course of the disease. None of the previously mentioned treatment options affect the underlying pathogenic mechanisms of the disease.

\section{NEW DIRECTIONS FOR TREATMENT}

In recent years great strides have been made in understanding the pathogenesis of chronic inflammatory rheumatic diseases, including AS. This progress is due largely to advances in molecular biology and biotechnology that allow researchers to examine the molecular mechanisms of inflammatory processes. The pathogenesis of AS is likely to be multifactorial and include genetic, immunological, and environmental mechanisms that may act in concert or may be intertwined. ${ }^{40-42}$

In the past few years, tumour necrosis factor alpha (TNF $\alpha)$ has been identified as a key regulatory cytokine in the inflammatory cascade and has been the focus of research in the pathogenesis and treatment of rheumatic and other inflammatory disease states.

$\mathrm{TNF} \alpha$ is the key proinflammatory cytokine involved in the pathological inflammatory process of rheumatoid arthritis $(\mathrm{RA})^{43}$ and Crohn's disease, ${ }^{44}$ a condition strongly associated with AS in either its subclinical or clinical form. ${ }^{45}$ In RA, TNF $\alpha$ mediates inflammation, development of pannus, and joint destruction. Its effects on endothelial cells result in up regulation of adhesion molecules, which facilitates leucocyte trafficking (E-selectin, intercellular adhesion molecule-1, vascular cell adhesion molecule-1) and stimulates angiogenesis mediated by vascular endothelial growth factor ${ }^{46}$; TNF $\alpha$ also stimulates inflammatory cells (up regulates proinflammatory cytokines including interleukin 1, interleukin 6, and granulocyte macrophage colony stimulating factor) and synovial fibroblasts (stimulates synthesis of metalloproteinases that mediate bone and cartilage destruction, and induces proliferation of fibroblasts $).{ }^{46}$ In patients with RA there is a correlation between serum TNF $\alpha$ levels and disease severity and joint pain. ${ }^{47}$ 
In Crohn's disease, TNF $\alpha$ up regulates cell surface adhesion molecules, platelet activating factor, and interleukin 8 in endothelial cells, and stimulates local production of chemotactic substances, thus facilitating the recruitment of circulating inflammatory cells to sites of mucosal inflammation. ${ }^{44}$ As in $\mathrm{RA}, \mathrm{TNF} \alpha$ in Crohn's disease induces the production of other proinflammatory cytokines. ${ }^{34}$ In both RA and Crohn's disease, neutralisation of the biological effects of $\mathrm{TNF} \alpha$ has proved to be effective in managing these two diseases. ${ }^{46} 48-50$

Clinical trials with the two anti-TNF $\alpha$ agents currently in clinical use, infliximab (a monoclonal anti-TNF $\alpha$ antibody) and etanercept (a soluble TNF $\alpha$ receptor fusion protein), have established their efficacy in reducing the signs and symptoms of RA. ${ }^{50}{ }^{51}$ Perhaps the most exciting finding of these studies is radiographic evidence that pharmacologically blocking the action of TNF $\alpha$ is an effective mechanism for halting or retarding the progression of joint damage in RA. ${ }^{5253}$ Infliximab and etanercept have recently become available for clinical use in the treatment of RA. Infliximab, in combination with methotrexate, is approved for reducing signs and symptoms, improving physical function, and inhibiting the progression of structural damage in patients with moderately to severely active RA who have had an inadequate response to methotrexate. Infliximab is also approved for the treatment of moderately to severely active Crohn's disease inadequately responsive to conventional treatment. Etanercept is approved for the treatment of moderately to severely active RA in patients who have inadequate responses to one or more DMARD, or in combination with methotrexate in patients who do not respond adequately to methotrexate alone.

Several lines of evidence suggest a role of TNF $\alpha$ in the pathogenesis of AS. Firstly, the overexpression of TNF $\alpha$ has been documented in sacroiliac joints of patients with AS. ${ }^{54}$ Secondly, increased levels of TNF $\alpha$ have been detected in synovial fluid and synovial tissue from patients with psoriatic arthritis, another SpA. ${ }^{55}$ Thirdly, in vitro studies have demonstrated high concentrations of TNF $\alpha$ in gut mucosa biopsy samples taken from patients with Crohn's disease, ${ }^{57} 58$ an inflammatory bowel disease strongly associated with AS. ${ }^{45}$ Finally, studies have shown abnormalities in the helper T cell subtype 1 (Thl) cytokine profile in patients with AS and related SpAs, ${ }^{59}$ and in gut mucosal lymphocytes from patients with SpA. ${ }^{61}$ The latter finding links the gut immune system abnormalities to the pathogenesis of SpAs.

The hypothesis that TNF $\alpha$ has an important role in the pathogenesis of AS and related SpAs has been validated by the observed ability of anti-TNF $\alpha$ therapy (infliximab) to reverse Thl cytokine abnormalities. ${ }^{60}$ Reduction in the thickness of the synovial layer has been seen in patients with SpA who are receiving anti-TNF $\alpha$ therapy, together with down regulation of endothelial adhesion molecules and reduction of inflammatory infiltrates in the synovial sublining area. ${ }^{62}$ Randomised, double blind, placebo controlled clinical trials have demonstrated the significant efficacy of infliximab ${ }^{63}$ and etanercept ${ }^{64}$ in reducing disease activity in patients with AS. Controlled studies have also shown their efficacy in psoriatic arthritis and other forms of SpAs. ${ }^{65-67}$ However, it is yet to be determined whether the immunomodulatory effects of anti-TNF $\alpha$ therapy that have thus far been observed will alter radiographic disease progression. There are also some new treatments under study, including pamidronate and thalidomide. ${ }^{689}$

The emergence of data on the pathogenesis of these diseases and the molecular mechanism of the inflammatory process, as well as the development of new treatments that redress underlying pathogenic abnormalities, appear to be occurring in tandem. The workshop on the new treatment strategies was a timely event that provides a solid foundation to enable dramatic improvement in the management of patients with AS and related SpAs in the near future. For the first time there is a real possibility of controlling and modifying the course of these diseases for the betterment of the patients.

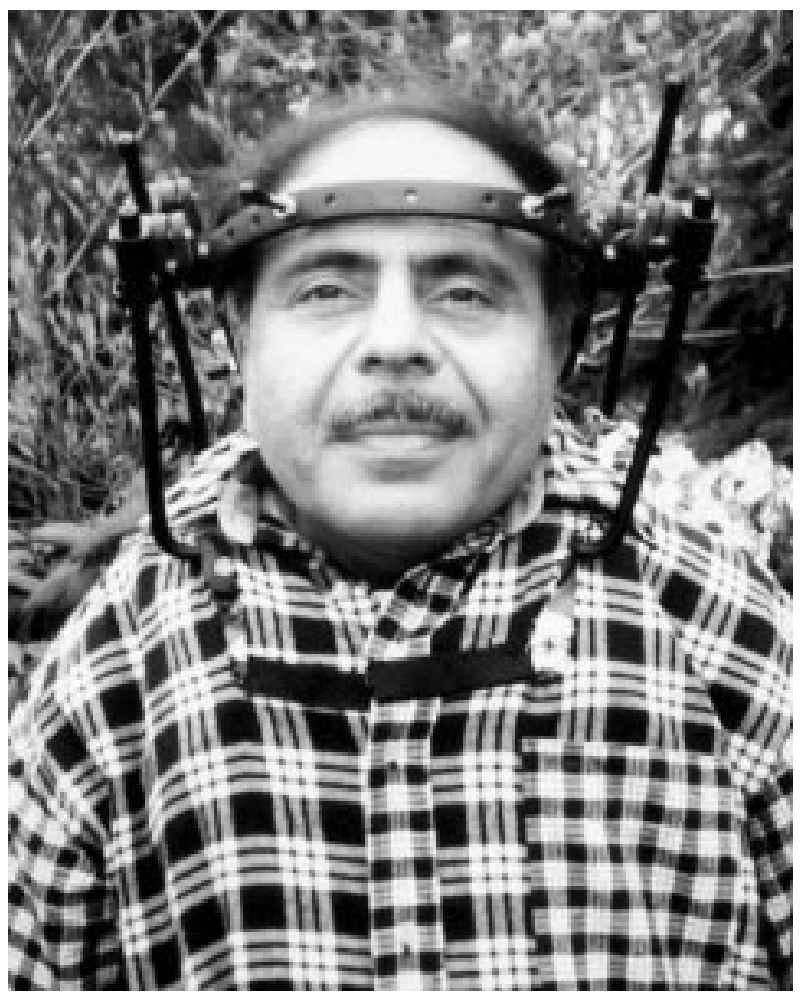

Figure 2 The author, MA Khan, who has had AS for the past 46 years. Reproduced with permission of the author and Blackwell Publishing from MA Khan. Spondyloarthropathies. In: Hunder G, ed. A tlas of rheumatology. 0 xford, UK, Blackwell Science;

1998:5.1-24.

This review on the therapeutic advances in the management of AS does not cover surgical advances, such as cervical spinal fracture management with halo and vest. Figure 2 highlights these advances, showing a picture of the author who has had AS for the past 46 years.

Author's affiliations

M A Khan, Case W estern Reserve University, Cleveland, 0 hio, USA Correspondence to: Dr M A Khan, Case W estern Reserve University, University School of M edicine, Division of Rheumatology, 2500

MetroHealth Drive, Cleveland, 0 hio 44145, USA; mak9@po.cwru.edu

\section{REFERENCES}

1 Khan MA. Ankylosing spondylitis: clinical features. In: Hochberg M, Silman A, Smolen J, W einblatt M, W eisman M, eds. Rheumatology. 3rd ed. London, Mosby-W olfe. In press.

2 Khan MA. Update on spondyloarthropathies. Ann Intern Med 2002;18:896-907

3 Mau W, Zeidler H, Mau R, Majewski A, Freyschmidt J, Stangel W, et al. Clinical features and prognosis of patients with possible ankylosing spondylitis. Results of a 10 -year followup. J Rheumatol 1988;15:1109-14

4 Mau W, Zeidler H, Mau R, Majewski A, Freyschmidt J, Stangel W, et al. Evaluation of early diagnostic criteria for ankylosing spondylitis in a 10 year follow-up. Z Rheumatol 1990;49:82-7

5 Feldtkeller E, Bruckel J, Khan MA. Scientific contributions of ankylosing spondylitis patient advocacy groups. Curr 0 pin Rheumatol 2000;12:239-47.

6 Carette S, G raham D, Little H, Rubenstein J, Rosen P. The natural course of ankylosing spondylitis. Arthritis Rheum 1983;26:186-90.

7 Burgos-Vargas R, Petty RE. Juvenile ankylosing spondylitis. Rheum Dis Clin N orth Am 1992:18:123-42.

8 Olivieri I, Salvarani C, Cantini F, Ciancio G, Padula A. Ankylosing spondylitis and undifferentiated spondyloarthropathies: a clinical review and description of a disease subset with older age at onset. Curr 0 pin Rheumatol 2001;13:280-4.

9 Ward MM. Functional disability predicts total costs in patients with ankylosing spondylitis. Arthritis Rheum 2002;46:223-31. 
10 Boonen A van der Heijde D, Landewe R, Rutten M, Spoorenberg A, Schouten $\mathrm{H}$, et al. W ork status and productivity costs due to ankylosing spondylitis: comparison among three European countries. Ann Rheum Dis 2002;61:429-37.

11 van der Linden S, Valkenburg HA, Cats A. Evaluation of diagnostic criteria for ankylosing spondylitis. A proposal for modification of the New York criteria. Arthritis Rheum 1984:27:361-8.

12 Zeidler $\mathbf{H}, \mathbf{M}$ au W, Khan M A. Undifferentiated spondyloarthropathies. Rheum Dis Clin N orth Am 1992;18:187-202

13 Dougados $M$, van der Linden S, Juhlin R, Huitfeldt B, Amor B, Calin A, et al. The European Spondylarthropathy Study $\mathrm{G}$ roup preliminary criteria for the classification of spondylarthropathy. Arthritis Rheum 1991;34:1218-30

14 Amor B, Dougados M, Listrat V, Menkes CJ, Roux H, Benhamou C, et al. A re classification criteria for spondylarthropathy useful as diagnostic criteria? Rev Rhum Engl Ed 1995;62:10-15

15 Amor B, Dougados M, Khan M A. M anagement of refractory ankylosing spondylitis and related spondyloarthropathies. Rheum Dis Clin N orth Am 1995;21:117-28.

16 Bakker C, Boers M, van der Linden S. M easures to assess ankylosing spondylitis: taxonomy, review, and recommendation. J Rheumatol $1993 ; 20: 1724-30$

17 Amor B, Santos RS, N ahal R, Listrat V, Dougados M. Predictive factors for the long term outcome of spondyloarthropathies. I Rheumatol $1994 ; 21: 1789-90$

18 van der Heijde D, Bellamy N, Calin A, Dougados M, Khan MA, van der Linden $\mathrm{S}$. Preliminary core sets for endpoints in ankylosing spondylitis. Assessments in Ankylosing Spondylitis W orking G roup. Rheumatol 1997:24:2225-9.

19 van der Heiide D, Calin A, Dougados M, Khan M A, van der Linden S, Bellamy N. Selection of instruments in the core set for DC -ART, SM ARD, physical therapy, and clinical record keeping in ankylosing spondylitis. Progress report of the ASAS W orking G roup. Assessments in Ankylosing Spondylitis. I Rheumatol 1999;26:951-4.

20 Dougados $M$, Revel M, Khan M A. Spondyloarthropathy treatment: progress in medical therapy. Baillieres Clin Rheumatol 1998;12:717-36.

21 Palferman TG, W eblely M. A comparative study of nabumetone and indomethacin in ankylosing spondylitis. Eur J Rheumatol Infla mm 1991;11:23-9

22 Calin A. Clinical use of tolmetin sodium in patients with ankylosing spondylitis: a review. J Clin Rheumatol 1983;23:301-8.

23 Schwarzer AC, Cohen M, A rnold MH, Kelly D, M CN aught P, Brooks $P M$. Tenoxicam compared with diclofenac in patients with ankylosing spondylitis. Curr Med Res 0 pin 1990;11:648-53.

24 Amor B, Dougados M, Listrat V, M enkes CJ, Dubost J,, Roux H, et al. Evaluation des critères de spondylarthropathies d'Amor et de l'European Spondylarthropathy Study Group (ESSG). Une etude transversale de 2229 patients. Ann M ed Interne (Paris) 1991;142:85-9.

25 Coles LS, Fries JF, Kraines RG, Roth SH. From experiment to experience: side effects of nonsteroidal anti-inflammatory drugs. Am J Med $1983 ; 74: 820-8$

26 Paulus HE. FDA arthritis advisory committee: serious gastrointestinal toxicity of nonsteroidal anti-inflammatory drugs, etc. Arthritis Rheum 1988;31:1450-1.

27 Silverstein FE, Faich G, Goldstein JL, Simon LS, Pincus T, W helton A, et al. G astrointestinal toxicity with celecoxib vs nonsteroidal anti-inflammatory drugs for osteoarthritis and rheuma toid arthritis: the CLASS study: a randomized controlled trial. JAMA 2000;248:1247-55.

28 Simon LS, W eaver AL, G raham DY, Kivitz AJ, Lipsky PE, Hubbard RC, et al. Antiinflammatory and upper gastrointestinal effects of celecoxib in rheumatoid arthritis: a randomized controlled trial. JAM A 1999;282:1921-8

29 Hochberg $\boldsymbol{M}$, ed. Coxibs: evolution of a revolutionary class. Evolving class and issues surrounding COX-2 inhibitors. Cleveland Clin J Med 2002;69(suppl 1):SI-1-84

30 Dougados $M$, Behier JM, Jolchine I, Calin A, van der Heijde D, 0 livieri l, et al. Efficacy of celecoxib, a cyclooxygenase 2 -specific inhibitor, in the treatment of ankylosing spondylitis: a six-week controlled study with comparison against placebo and against a conventional nonsteroidal antiinflammatory drug. Arthritis Rheum 2001;44:180-5.

31 Dougados $\mathbf{M}$, van der Linden $S$, Leirisalo-Repo $M$, Huitfeldt $B$, Juhlin R, Zeidler $\mathrm{H}$, et al. Sulfasalazine in the treatment of spondyloarthropathy. A randomized, multicenter, double-blind, placebo-controlled study. Arthritis Rheum 1995;38:618-27.

32 Clegg DO, Reda DJ, W eisman MH, Blackburn W D, Cush JJ, Cannon $\mathrm{GW}$, et al. Comparison of sulfasalazine and placebo in the treatment of ankylosing spondylitis: a Department of Veterans Affairs Cooperative Study. Arthritis Rheum 1996;39:2004-12

33 Biasi D, Carletto A, Caramaschi P, Pacor M L, Maleknia T, Bambara LM Efficacy of methotrexate in the treatment of ankylosing spondylitis: a three-year open study. Clin Rheumatol 2000;19:114-17.

34 Altan L, Bingol U, Karakoc Y, Aydiner S, Yurtkuran M. Clinical investigation of methotrexate in the treatment of ankylosing spondylitis. Scand J Rheumatol 2001;30:255-9

35 Sampaio-Barros PD, C ostallat LT, Bertolo M B, N eto JF, Samara AM. $M$ ethotrexate in the treatment of ankylosing spondylitis. Scand J Rheumatol 2000;29:160-2.

36 Roychaudhry B, Bintley-Bagot S, Hunt J, Tunn EJ. M ethotrexate in severe ankylosing spondylitis: a randomized placebo controlled, double-blind observer study [abstract]. Rheumatology 2001;40 (suppl 1):43.

37 Williamson L, Illingworth $\mathrm{H}$, Smith D, M owat A. O ral quinine in ankylosing spondylitis: a randomized placebo controlled double blind crossover trial. J Rheuma tol 2000;27:2054-5
38 Braun J, Bollow M, Seyrekbasan F, Haberle HJ, Eggens U, Mert A, et al. Computed tomography guided corticosteroid injection of the sacroiliac joint in patients with spondyloarthropathy with sacroiliitis: clinical outcome and follow-up by dynamic magnetic resonance imaging. J Rheumatol 1996;23:659-64.

39 Gunaydin I, Pereira PL, Daikeler T, M ohren M. Trubenbach J, Schick F, et al. Magnetic resonance imaging guided corticosteroid injection of the sacroiliac joints in patients with therapy resistant spondyloarthropathy: a pilot study. J Rheumatol 2000;27:424-8.

40 Granfors K, Märker-Hermann E, De Keyser P, Khan M A, Veys EM, Yu DT. The cutting edge of spondyloarthropathy research in the millennium. Arthritis Rheum 2002;46:606-13.

41 Khan MA, Ball EJ. Ankylosing spondylitis and genetic aspects. Baillieres Best Pract Res Clin Rheumatol (in press).

42 Laval SH, Timms A, Edwards S, Bradbury L, Brophy S, M ilicic A, et al. $W$ hole-genome screening in ankylosing spondylitis: evidence of non-M HC geneticsusceptibility loci. Am J Hum G enet 2001;68:916-26.

43 Feldmann M, Brennan FM, Maini RN. Role of cytokines in rheumatoid arthritis. Ann Rev Immunol 1996;14:397-440.

44 Van Deventer SJ. Tumour necrosis factor and Crohn's disease. G ut 1997;40:443-8.

45 Mielants H, Veys EM, Cuvelier C, De Vos M. Course of gut inflammation in spondylarthropathies and therapeutic consequences. Baillieres $\mathrm{Clin}$ Rheumatol 1996;10:147-64

46 Kavanaugh AF. Anti-tumor necrosis factor- $\alpha$ monoclonal antibody therapy for rheumatoid arthritis. Rheum Dis Clin N orth Am 1998:24:593-614

47 Beckham JC, Caldwell DS, Peterson BL, Pippen AM, Currie M S, Keefe FJ, et al. Disease severity in rheumatoid arthritis: relationships of plasma tumor necrosis factor-alpha, soluble interleukin 2 -receptor, soluble CD4/CD8 ratio, neopterin, and fibrin D-dimer to traditional severity and functional measures. J Clin Immunol 1992;12:353-61.

48 Targan SR, Hanauer SB, van Deventer SJ, M ayer L, Present DH, Braakman T, et al. A short-term study of chimeric monoclonal antibody CA2 to tumor necrosis factor alpha for Crohn's disease. Crohn's Disease CA2 Study Group. N Engl J Med 1997;337:1029-35.

49 Hanauer SB, Lichtenstein G R, Columbel J-F, M ayer L, Schreiber S, Rachmilewicz D. Maintenance infliximab (Remicade) is safe, effective and steroid sparing in Crohn's disease: preliminary results from the ACCEN T I trial [abstract]. G astroenterology 2001;120:A21.

50 Miani R, St Clair EW, Breedveld F, Furst D, Kalden J, W eisman M, et al. Infliximab (chimeric anti-tumour necrosis factor alpha monoclonal antibody) versus placebo in rheumatoid arthritis patients receiving concomitant methotrexate: a randomized phase III trial. ATRRACT Study G roup. Lancet 1999;354:1932-9.

51 Moreland LW, Schiff M W H, Baumgartner SW, Tindall EA, Fleischmann RM, Bulpitt KJ, et al. Etanercept therapy in rheumatoid arthritis. A randomized, controlled trial. Ann Intern Med 1999:130:478-86.

52 Lipsky P, St Clair W, Furst D, Breedveld F, Smolen J, Kalden JR, et al. 54 -w eek clinical and radiographic results from the ATRRACT trial: a phase III study of infliximab (Remicade ${ }^{\circledast}$ ) in patients with active RA despite methotrexate [abstract]. A rthritis Rheum 1999;42:S401.

53 Finck B, Martin R, Fleischmann R, Moreland L, Schiff M, Bathon J. A phase III trial of etanercept vs. methotrexate (MTX) in early rheumatoid arthritis (Enbrel ERA trial) [abstract]. Arthritis Rheum 1999;42:S177.

54 Braun J, Bollow M, N eure L, Seipelt E, Seyrekbasan F, Herbst H, et al. Use of immunohistologic and in situ hybridization techniques in the examination of sacroiliac joint biopsy specimens from patients with ankylosing spondylitis. A rthritis Rheum 1995;38:499-505.

55 Partsch G, Steiner G, Leeb BF, Dunky A, Broll H, Smolen JS. Highly increased levels of tumor necrosis factor-alpha and other proinflammatory cytokines in psoriatic arthritis synovial fluid. J Rheumatol $1997 ; 24: 518-23$

56 Ritchlin C, Haas-Smith SA, Hicks D, Cappuccio J, O sterland CK, Looney R. Patterns of cytokine production in psoriatic synovium. J Rheumatol $1998 ; 25: 1544-52$

57 MacDonald TT, Hutchings P, Choy MY, Murch S, Cooke A. Tumour necrosis factor-alpha and interferon-gamma production measured at the single cell level in normal and inflamed human intestine. Clin Exp Immunol 1990;81:301-5.

58 Murch SH, Braegger CP, W alker-Smith JA, M acDonald $\Pi$. Location of tumour necrosis factor alpha by immunohistochemistry in chronic infla mmatory bowel disease. Gut 1993;34:1705-9.

59 Rudwaleit $M$, Siegert S, Yin Z, Eick J, Thiel A, Radbruch A, et al. Low T cell production of TN Falpha and IFN gamma in ankylosing spondylitis: its relation to HLA -B27 and influence of the TN F-308 gene polymorphism. Ann Rheum Dis 2001;60:36-42.

60 Baeten D, Van Damme N, Van den Bosch F, Kruithof E, De Vos M, $M$ ielants $\mathrm{H}$, et al. Impaired Th1 cytokine production in spondyloarthropathy is restored by anti-TN Falpha. Ann Rheum Dis 2001;60:750-5

61 Van Damme N, De Vos M, Baeten D, Demetter P, M ielants $H$, Verbruggen $\mathrm{G}$, et al. Flow cytometric analysis of gut mucosal lymphocytes supports an impaired Th1 cytokine profile in spondyloarthropathy. Ann Rheum Dis 2001:60:495-9.

62 Baeten D, Kruithof E, Van den Bosch F, Demetter P, Van Damme N Cuvelier $\mathrm{C}$, et al. Immunomodulatory effects of anti-tumor necrosis factor $\alpha$ therapy on synovium in spondyloarthropathy. Histologic findings in eight patients from an open-label pilot study. Arthritis Rheum 2001;44:186-95

63 Braun J, Brandt J, Listing J, Zink A, A ten R, Golder W, et al. Treatment of active ankylosing spondylitis with infliximab: a randomized controlled multicentre trial. Lancet 2002;359:1187-93. 
64 Gorman JD, Sack KE, Davis JC Jr. Treatment of ankylosing spondylitis by inhibition of tumor necrosis factor alpha. N Engl J Med 2002;346:1349-56.

65 Van den Bosch F, Kruithof E, Baeten D, Herssens A, de Keyser F, $M$ ielants $\mathrm{H}$, et al. Randomized double-blind comparison of chimeric monoclonal antibody to tumor necrosis factor alpha (infliximab) versus placebo in active spondyloarthropathy. Arthritis Rheum 2002;46:755-65.

66 Mease PJ, G offe BS, M etz J, VanderStoep A, Finck B, Burge DJ. Etanercept in the treatment of psoriatic arthritis and psoriasis: a randomised trial. Lancet 2000;356:385-90.
67 Lovell DJ, G iannini EH, Reiff A, Cawkwell GD, Silverman ED, N octon IJ, et al. Etanercept in children with polyarticular juvenile rheumatoid arthritis. Pediatric Rheumatology Collaborative Study Group. N Engl J Med 2000;342:763-9.

68 Breban M, Gombert B, Amor B, Dougados M. Efficacy of thalidomide in the treatment of refractory ankylosing spondylitis. A rthritis Rheum $1999 ; 42: 580-1$

69 Maksymowych WP, Jhangri GS, Fitgerald AA, LeClerg S, Chiu P, Yan $A$, et al. A six-month randomized controlled, double-blind, dose-response comparison of intravenous pamidronate $(60 \mathrm{mg}$ versus $10 \mathrm{mg})$ in the treatment of non-steroidal antiinflammatory drug-refractory ankylosing spondylitis. Arthritis Rheum 2002:46:766-73.

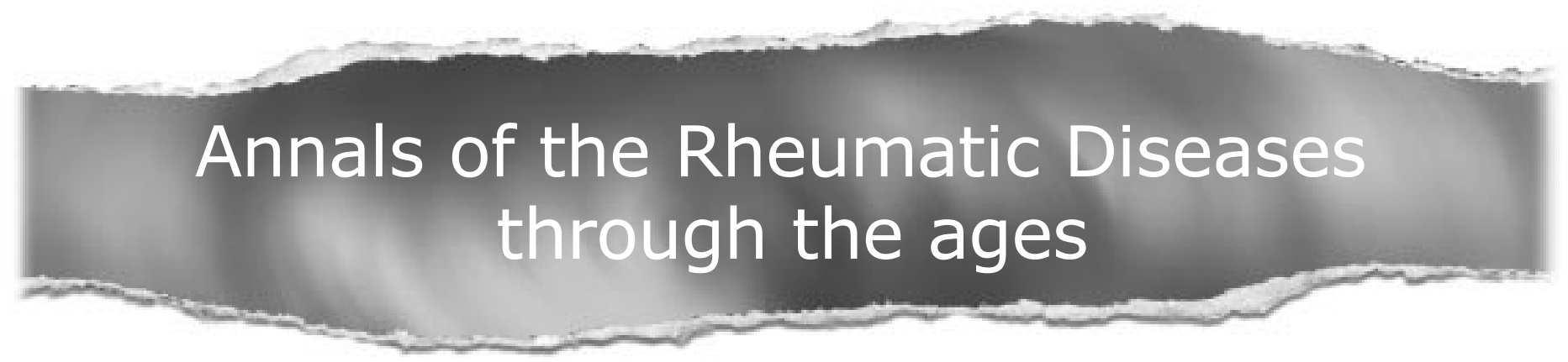

Browse the Archive

Annals of the Rheumatic Diseases online has an archive of content dating back to 1965. Full text from 1997; abstracts from 1975; table of contents from 1965

www.annrheumdis.com 